\title{
Metabolites and dead-end products from the microbial oxidation of quaternary ammonium alcohols
}

\author{
Journal Article \\ Author(s): \\ Kaech, Andres; Hofer, Martina; Rentsch, Daniel; Schnider, Christian; Egli, Thomas \\ Publication date: \\ 2005-10 \\ Permanent link: \\ https://doi.org/10.3929/ethz-b-000046680
}

Rights / license:

In Copyright - Non-Commercial Use Permitted

Originally published in:

Biodegradation 16(5), https://doi.org/10.1007/s10532-004-5164-5 


\title{
Metabolites and dead-end products from the microbial oxidation of quaternary ammonium alcohols
}

\author{
Andres Kaech ${ }^{1}$, Martina Hofer ${ }^{1}$, Daniel Rentsch ${ }^{2}$, Christian Schnider $^{3}$ \& Thomas Egli ${ }^{1} *$ \\ ${ }^{1}$ Swiss Federal Institute for Water Resources and Water Pollution Control (EAWAG), Environmental \\ Microbiology, P.O. Box 611, Überlandstrasse 133, CH-8600 Dübendorf, Switzerland; ${ }^{2}$ Swiss Federal \\ Laboratories for Materials Testing and Research (EMPA), Überlandstrasse 129, CH-8600 Dübendorf, \\ Switzerland; ${ }^{3}$ Institute of Organic Chemistry, University of Zurich, Winterthurerstr. 190, CH-8057 Zürich, \\ Switzerland (*author for correspondence: e-mail: thomas.egli@eawag.ch)
}

Accepted 21 October 2004

Key words: biodegradation, cationic surfactants, electrophoresis mass spectrometry, NMR, oxidoreductase

\begin{abstract}
Methyl-triethanol-ammonium originates from the hydrolysis of the parent esterquat surfactant, which is used as softener in fabric care. The initial steps of the catabolism were investigated in cell-free extracts of the bacterial strain MM 1 able to grow with methyl-triethanol-ammonium as sole source of carbon, energy and nitrogen. The initial degradation of methyl-triethanol-ammonium is an enzymatically catalyzed reaction, located in the particulate fraction of strain MM 1. The oxygen dependent reaction occurred also in presence of phenazine methosulfate as an alternative electron acceptor. As soon as one ethanol group of methyl-triethanol-ammonium was oxidized to the aldehyde, cyclic hemiacetals were formed by intramolecular cyclization. The third ethanol group of methyl-triethanol-ammonium was oxidized to the aldehyde and the carboxylic acid sequentially. The structurally related compounds dimethyl-diethanol-ammonium and choline were oxidized as well, whereas $( \pm)$-2,3-dihydroxypropyl-trimethyl-ammonium was not converted at all. The structures of the metabolites were established by $1 \mathrm{D}$ and $2 \mathrm{D}{ }^{1} \mathrm{H},{ }^{13} \mathrm{C}$ and ${ }^{14} \mathrm{~N} \mathrm{NMR}$ spectroscopy and by capillary electrophoresis mass spectrometry.

Abbreviations: CE-MS - capillary electrophoresis mass spectrometry; DM - dimethyl-diethanol-ammonium; HMBC - heteronuclear multiple bond correlation; HMQC - heteronuclear multiple quantum coherence; HSQC - heteronuclear single quantum coherence; INT - iodonitrotetrazolium chloride; MM methyl-triethanol-ammonium; PF - particulate fraction of the cell-free extract; PMS - phenazine methosulfate; QAA - quaternary ammonium alcohol; TM - ( \pm )-2,3-dihydroxypropyl-trimethyl-ammonium
\end{abstract}

\section{Introduction}

The quaternary ammonium alcohols methyl-triethanol-ammonium (MM), dimethyl-diethanol-ammonium (DM) and 2,3-dihydroxypropyl-trimethyl-ammonium (TM) are the three mainly used head groups in esterquat surfactants, that are applied as softeners in fabric care (Krueger et al. 1998). When reaching surface water or sewage treatment plants, the parent esterquat surfactants hydrolyze rapidly, abiotically and/or biocatalyzed to the fatty acids and the quaternary ammonium alcohols (QAAs) (Hellberg et al. 2000; Krueger et al. 1998; Puchta et al. 1993; Simms et al. 1992). The biodegradability of both, the parent esterquat surfactant and the QAA, has been investigated in standard OECD (Organization for Economic Cooperation and Development) biodegradation tests. Based on these tests they are considered as readily and ultimately biodegradable 
(Krueger et al. 1998; Puchta et al. 1993; Simms et al. 1992; Waters et al. 2000). Whereas the fatty acids are expected to biodegrade via the common fatty acid catabolism ( $\beta$-oxidation), the enzymes involved in the degradation of the QAA MM (and the other QAAs) are not yet known. Considering the widespread application of these QAAs and the design and development of similar compounds, it is important to know the microbial strategies and the biochemical pathways of their biodegradation. We isolated a microbial strain growing with MM as sole source of carbon, energy and nitrogen (Kaech 2002). In this work, the initial steps in the catabolism of MM were investigated in the cellfree extracts of the isolated strain. The metabolites built by the consumption of structurally related substrates were examined as well.

\section{Materials and methods}

\section{Chemicals}

The quaternary ammonium alcohols (QAAs) were provided by Unilever (SEAC Safety and Environmental Assessment Center, Unilever Research, Port Sunlight, UK) as the iodide salts in aqueous solution in $>99 \%$ purity (impurities consisting mainly of non-methylated tertiary amines). Dry weights: MM, 84.9\%; DM, 85.1\%; TM, 51.7\%. All other chemicals were purchased from Fluka, Buchs, Switzerland, unless indicated otherwise.

\section{Bacterial strains and cultivation}

All experiments were performed with cells or cellfree extracts of strain MM 1 isolated in our laboratory with $\mathrm{MM}$ as the sole source of carbon, energy and nitrogen. Strain MM 1 was analyzed by sequencing the $16 \mathrm{~S}-\mathrm{rDNA}$ gene. The sequence was deposited in the EMBL sequence database (European Molecular Biology Laboratory, Heidelberg, Germany) and is accessible using the assigned number AJ440751. The alignment of the sequence of strain MM 1 to the sequences in the EMBL database provided a closest relationship to Rhodobacter sphaeroides with a similarity of $94 \%$ identical base pairs only. Additionally, strain MM 1 did not exhibit the key properties of the genus Rhodobacter (Kaech 2002; Kaech et al. unpublished results). Strain MM 1 has been deposited at the German Culture Collection (DSMZ, Braunschweig, deposition number DSM 16851). For growth in batch cultures, a synthetic medium (SM) was used ( $\mathrm{g} \mathrm{l}^{-1}$ deionized water): $\mathrm{MgSO}_{4} \times 7 \mathrm{H}_{2} \mathrm{O}$, 0.3; $\mathrm{CaCl}_{2} \times 2 \mathrm{H}_{2} \mathrm{O}, 0.02 ; \mathrm{Na}_{2} \mathrm{HPO}_{4} \times 2 \mathrm{H}_{2} \mathrm{O}, 2.05$; $\mathrm{KH}_{2} \mathrm{PO}_{4}, 1.30 ; 1 \mathrm{ml}$ of trace element stock solution prepared according to Pfennig et al. (1981), $\left(\mathrm{g} \mathrm{l}^{-1}\right.$ deionized water: $\mathrm{FeCl}_{2} \times 4 \mathrm{H}_{2} \mathrm{O}, 4.5$; $\mathrm{MnCl}_{2} \times 4 \mathrm{H}_{2} \mathrm{O}, 0.3 ; \mathrm{CoCl}_{2} \times 6 \mathrm{H}_{2} \mathrm{O}, 0.36 ; \mathrm{ZnCl}_{2}$, $0.21 ; \mathrm{CuCl}_{2} \times 2 \mathrm{H}_{2} \mathrm{O}, \quad 0.045 ; \quad \mathrm{Na}_{2} \mathrm{MoO}_{4} \times 2 \mathrm{H}_{2} \mathrm{O}$, $0.075 ; \quad \mathrm{H}_{3} \mathrm{BO}_{3}, \quad 0.18 ; \quad \mathrm{NiCl}_{2} \times \quad 6 \mathrm{H}_{2} \mathrm{O}, \quad 0.075$; $\mathrm{Na}_{4}$ EDTA $\left.\times 4 \mathrm{H}_{2} \mathrm{O}, 14.023\right) ; 1 \mathrm{ml}$ of vitamin stock solution ( $\mathrm{mg}^{-1}$ deionized water: pyridoxine $\mathrm{HCl}$, 100; biotin, 20; folic acid, 20 and $50 \mathrm{mg}$ of each: thiamine $\mathrm{HCl}$, riboflavin, nicotinic acid, D-Capantothenic acid, $p$-amino benzoic acid, lipoic acid, nicotinamide and vitamin $\mathrm{B} 12$ ). The $\mathrm{pH}$ of the medium was always 7.0. For batch media $\mathrm{MgSO}_{4} \times 7 \mathrm{H}_{2} \mathrm{O}, \quad \mathrm{CaCl}_{2} \times 2 \mathrm{H}_{2} \mathrm{O}$ and trace elements were dissolved in nanopure water and autoclaved separately in Erlenmeyer flasks. The phosphate buffer, vitamins and the carbon source of choice were added after sterilization to the cooled-down medium by sterile filtration, using sterile Millex-GP filters of $0.22 \mu \mathrm{m}$ pore size (Millipore, Volketswil, Switzerland).

Cells of strain MM 1 were grown in batch cultures using 21 Erlenmeyer flasks containing $500 \mathrm{ml} \mathrm{SM}$ with 6 to $15 \mathrm{mM}$ of either MM, choline or acetate. For the growth with acetate ammonium chloride $(15 \mathrm{mM})$ was used as the nitrogen source. Cultures were incubated at $30{ }^{\circ} \mathrm{C}$ and $\mathrm{pH} 7$ and stirred at $500 \mathrm{rpm}$ to maintain excess oxygen concentration. For short-term storage, strain MM 1 was plated on 10-fold diluted tryptic soy agar or agar plates containing $\mathrm{SM}$ and $\mathrm{MM}(3 \mathrm{mM})$. For long-term preservation the strain was suspended in $30 \%$ glycerol and stored at $-80{ }^{\circ} \mathrm{C}$.

\section{Preparation of cell-free extracts}

Cells were harvested in the late exponential growth phase by centrifugation at $4{ }^{\circ} \mathrm{C}$ and $7000 \times g$ for 10 min (rotor: A 8.24, Kontron Instruments, Vietri Sul Mare, Campania, Italy). Cells were washed once and resuspended after repeated centrifugation with sodium phosphate buffer $(50 \mathrm{mM}, \mathrm{pH} 7)$. The buffer was prepared by solving $3.54 \mathrm{~g} \mathrm{l}^{-1}$ $\mathrm{NaH}_{2} \mathrm{PO}_{4} \times 2 \mathrm{H}_{2} \mathrm{O}$ and $4.86 \mathrm{~g} \mathrm{l}^{-1} \mathrm{Na}_{2} \mathrm{HPO}_{4} \times$ $2 \mathrm{H}_{2} \mathrm{O}$ in deionized water. Before breakage of the 
cells $\sim 20 \mathrm{mg} \mathrm{l}^{-1}$ of DNAse I (EC 3.1.21.1, Aldrich, Milwaukee WI, USA) was added. Initially, 1,4-dithio-D, L-threitol (DTT, $2 \mathrm{mM}$ ) was added to the cell suspension as well, but later DTT was omitted, since it was found to have no effect on enzyme activity in the protein fraction. The cells were broken by two passages through a French press (Aminco, Urbana, Illinois, USA) at 20,000 psi. After each passage the cell suspension and the French press were cooled with ice to $0{ }^{\circ} \mathrm{C}$. The crude extract was centrifuged for $30 \mathrm{~min}$ at $15,000 \times g$ to remove unbroken cells and cell debris (rotor as above). Subsequently, the cell-free extract was separated into a particulate (PF) and a supernatant soluble fraction by ultra-centrifugation at $180,000 \times g$ for 1 h (rotor: TFT 65.13, Kontron Instruments, Vietri Sul Mare, Campania, Italy). The soluble fraction was removed and the pellet was suspended in sodium phosphate buffer $(50 \mathrm{mM}, \mathrm{pH} 7)$ and will be referred to as the PF. Aliquots of the protein fractions were frozen at $-20{ }^{\circ} \mathrm{C}$ until used in assays. No reduction in activity was observed originating from freezing/thawing and storage of the samples. To determine protein concentrations the Bio-Rad enzyme assay was used according to the manual of the manufacturer (Bio-Rad Laboratories $\mathrm{GmbH}, \mathrm{Mu}-$ nich, Germany). Bovine serum albumin was used as standard (Sigma-Aldrich Chemie GmbH, Steinheim, Germany).

\section{Enzyme activity assays}

All assays were carried out in GC-Vials (Supelco Inc., Bellefonte PA, USA) of 5 to $20 \mathrm{ml}$ volume. Protein solutions $\left(0.4-1.0 \mathrm{mg} \mathrm{m}^{-1}\right)$ were incubated at $\mathrm{pH} 7.0$ at $30{ }^{\circ} \mathrm{C}$ under continuous stirring $(\sim 400 \mathrm{rpm})$. To stop the enzymatic reaction, aliquots removed from assays were heated either for $1 \mathrm{~min}$ in a water bath of $95^{\circ} \mathrm{C}$ or $1 \mathrm{M} \mathrm{HCl}$ was added (10\% of sample volume). Before analysis, acidified samples were neutralized with $1 \mathrm{M}$ $\mathrm{NaOH}(10 \%$ of sample volume) and the $\mathrm{pH}$ was controlled with test strips (Tritest $\mathrm{pH}$ 1-11, Macherey-Nagel, Düren, Germany). The consumption of QAAs and building up of products was monitored by ${ }^{1} \mathrm{H}$ NMR. We did not observe any changes in chemical composition of samples employing the two different work-up procedures. The oxygen dependence of the reaction was monitored by carrying out experiments in sealed vessels with a continuous nitrogen flow through the headspace. All solutions used in these experiments, except for the protein stock solution, were flushed with nitrogen for $10 \mathrm{~min}$ before adding them to the assay. The performance of the electron acceptors $\mathrm{NAD}^{+}, \mathrm{NADP}^{+}, \mathrm{PMS}$ or iodonitrotetrazolium chloride (INT) were tested by adding aliquots from stock solutions to the assays (final concentrations: PMS $4.5 \mathrm{mM}, \mathrm{NAD}^{+}$and $\mathrm{NADP}^{+}$ $3.2 \mathrm{mM}$, INT $0.5 \mathrm{ml}$ of a saturated stock solution in water was added to $4.5 \mathrm{ml}$ of the reaction mixture). For control experiments the protein solutions were heated in a water bath $\left(\sim 95^{\circ} \mathrm{C}\right)$ for 1 min prior to the addition of substrate(s).

\section{Chemical oxidation of $M M$}

The oxidation of one ethanol group of MM to the corresponding aldehyde was performed according to the method described by Dess and Martin (1983). Owing to the poor solubility of MM in dichloromethane $\alpha, \alpha, \alpha$-trifluorotoluene was used as solvent (Ogawa \& Curran 1997). Saturated solutions of the oxidizing reagent and $\mathrm{MM}$ in $\alpha, \alpha, \alpha$-trifluorotoluene were used for the synthesis. After the reaction, residual MM and its oxidation products were extracted from the $\alpha, \alpha, \alpha$-trifluorotoluene reaction mixture twice with $\mathrm{H}_{2} \mathrm{O}$. The combined water phase was freeze-dried and the residue was dissolved in $\mathrm{D}_{2} \mathrm{O}$ for NMR analysis.

\section{Nuclear magnetic resonance spectroscopy}

The samples for NMR analysis were prepared either by carrying out the enzyme assays using a sodium phosphate buffer $\left(50 \mathrm{mM}, \mathrm{pH}\right.$ 7) in $\mathrm{D}_{2} \mathrm{O}$ or by diluting aliquots removed from the assays $1 / 10$ with $\mathrm{D}_{2} \mathrm{O}$ (Aldrich, Milwaukee WI, USA) to enable deuterium lock. The ${ }^{1} \mathrm{H},{ }^{13} \mathrm{C}$ and ${ }^{14} \mathrm{~N}$ NMR spectra were recorded to follow enzymatic activity and to elucidate the structure of the reaction products without any further purification or filtration of the solutions. NMR spectra were measured on a Bruker AMX-400 NMR spectrometer at $300 \mathrm{~K}$ using a $5 \mathrm{~mm}$ broadband probe. The ${ }^{1} \mathrm{H}$ NMR $\left({ }^{13} \mathrm{C} ;{ }^{14} \mathrm{~N}\right)$ spectra were recorded at 400.13 $(100.61 ; 28.9) \mathrm{MHz}$ with the following parameters: $10.5(6.5 ; 13.5) \mu \mathrm{s} 90^{\circ}$ pulse lengths, appropriate number of transients for reasonable $\mathrm{S} / \mathrm{N}$ ratio, $8300(30,300 ; 5800) \mathrm{Hz}$ spectral widths, 32k (64k; $16 \mathrm{k})$ data points, and $15(2.5,1) \mathrm{s}$ relaxation delays. The ${ }^{1} \mathrm{H}$ NMR spectra were recorded with 
presaturation of the water resonance followed by a composite pulse sequence (Bax 1985). The ${ }^{13} \mathrm{C}$ and ${ }^{14} \mathrm{~N}$ NMR spectra were recorded using a WALTZ proton decoupling field of $2.3 \mathrm{kHz}$ during acquisition (Shaka et al. 1983). The ${ }^{1} \mathrm{H}\left({ }^{13} \mathrm{C}\right)$ chemical shifts are given in parts per million $(\mathrm{ppm})$ relative to the signals of sodium 3-trimethylsilyl-tetradeutero-propionate (TSP) at 0.00 (1.7) $\mathrm{ppm}$. The chemical shifts of the $N$-methyl groups of the substrates were used as internal reference for the ${ }^{1} \mathrm{H}$ and ${ }^{13} \mathrm{C}$ NMR spectra of the enzyme assays. The chemical shifts of $200 \mathrm{mM}$ solutions of the substrates $\mathrm{MM}, \mathrm{DM}$ and choline in $\mathrm{D}_{2} \mathrm{O}$ were determined relative to TSP $(18.7 \mathrm{mM})$ and are given in Table 1.

The ${ }^{14} \mathrm{~N}$ chemical shifts of the same samples were determined relative to the signal of pure nitromethane within a capillary at $0.0 \mathrm{ppm}$ and the remaining signals were used as internal reference for the NMR spectra recorded during enzyme assays. The ${ }^{1} \mathrm{H},{ }^{14} \mathrm{~N}$ heteronuclear multiple quantum coherence (HMQC) (Bax et al. 1983) experiments were performed using the above mentioned $90^{\circ}$ pulse lengths with the selection of a coupling constant of $4 \mathrm{~Hz}$ showing the best results. The data was processed in the phase sensitive mode to achieve a better resolution in the ${ }^{14} \mathrm{~N}$ dimension for the methyl-nitrogen correlation signals.

${ }^{1} \mathrm{H},{ }^{13} \mathrm{C}$ 2D correlation experiments were performed on a $5 \mathrm{~mm}$ broadband inverse probe with z-gradient $\left(100 \%\right.$ gradient strength of $\left.10 \mathrm{G} \mathrm{cm}^{-1}\right)$ and $90^{\circ}$ pulse lengths of $8.2 \mu \mathrm{s}\left({ }^{1} \mathrm{H}\right)$ and $10.5 \mu \mathrm{s}$ $\left({ }^{13} \mathrm{C}\right)$. The gradient selected heteronuclear single quantum coherence (HSQC Davis et al. 1992) heteronuclear multiple bond correlation (HMBC;

Table 1. ${ }^{1} \mathrm{H},{ }^{13} \mathrm{C}$ and ${ }^{14} \mathrm{~N}$ chemical shifts of $\mathrm{MM}, \mathrm{DM}$ and choline $\left(200 \mathrm{mM}\right.$ in $\left.\mathrm{D}_{2} \mathrm{O}\right)$ in ppm and coupling constants ${ }^{1} \mathrm{~J}\left({ }^{13} \mathrm{C},{ }^{14} \mathrm{~N}\right)$ in $\mathrm{Hz}$

\begin{tabular}{llccc}
\hline Position & & MM & DM & Choline \\
\hline 1 & $\delta\left({ }^{1} \mathrm{H}\right)$ & 3.26 & 3.23 & 3.21 \\
& $\delta\left({ }^{13} \mathrm{C}\right)$ & 54.6 & 56.7 & 58.4 \\
& ${ }^{1} \mathrm{~J}\left({ }^{13} \mathrm{C},{ }^{14} \mathrm{~N}\right)$ & 3.7 & 3.8 & 3.9 \\
2 & $\delta\left({ }^{1} \mathrm{H}\right)$ & 3.68 & 3.60 & 3.52 \\
& $\delta\left({ }^{13} \mathrm{C}\right)$ & 69.0 & 70.8 & 72.0 \\
\multirow{3}{*}{3} & ${ }^{1} \mathrm{~J}\left({ }^{13} \mathrm{C},{ }^{14} \mathrm{~N}\right)$ & 2.6 & 2.9 & 3.1 \\
& $\delta\left({ }^{1} \mathrm{H}\right)$ & 4.07 & 4.07 & 4.07 \\
& $\delta\left({ }^{13} \mathrm{C}\right)$ & 59.7 & 59.9 & 60.1 \\
& $\delta\left({ }^{14} \mathrm{~N}\right)$ & -322.5 & -328.1 & -333.8 \\
\hline
\end{tabular}

(Wilker et al. 1993)) experiments were performed with the selection of ${ }^{1} \mathrm{H},{ }^{13} \mathrm{C}$ coupling constants of $140(5) \mathrm{Hz}$, gradient strengths of $-40: 10$ (15:9:12), $2920 \times 4800 \mathrm{~Hz}$ spectral widths with a carbon decoupling field of $3.7 \mathrm{kHz}$ for the HSQC experiments (GARP decoupling; (Shaka et al. 1985)). Before processing the data matrices of $1024 \times 256$ were zero filled to $1024 \times 1024$. The HSQCTOCSY (Palmer et al. 1991) spectra were recorded with the selection of ${ }^{1} \mathrm{~J}\left({ }^{1} \mathrm{H},{ }^{13} \mathrm{C}\right)=140 \mathrm{~Hz}$ and a $29 \mu \mathrm{s} 90^{\circ}$ pulse length for the TOCSY transfer with a total mixing time of $114 \mathrm{~ms}$, applying the above mentioned carbon decoupling conditions, data matrices and processing conditions. The NOESY (Jeener et al. 1979) spectra were recorded with data matrices of $1024 \times 256$ (spectral widths of $2400 \times 2400 \mathrm{~Hz}$ ) with presaturation of the water resonance during the relaxation delay ( $2 \mathrm{~s})$ and the mixing time $(800 \mathrm{~ms})$.

Quantitative determinations were performed using the ${ }^{1} \mathrm{H}$ NMR signals of the $\mathrm{CH}_{3}$-groups of the corresponding compounds. The sum of all $\mathrm{CH}_{3}$-group integrals of a spectrum was set to $100 \%$ and the relative amounts of the substrates and products were calculated according to their relative intensities.

\section{Capillary electrophoresis mass spectrometry (CE-MS)}

CE-MS experiments were performed on a $\mathrm{HP}^{3 \mathrm{D}} \mathrm{CE}$ capillary electrophoresis system (Agilent Technologies, Waldbronn, Germany). The fusedsilica capillary $(50 \mu \mathrm{m}$ internal diameter, $90 \mathrm{~cm}$ length, Agilent Technologies) was thermostated at $25{ }^{\circ} \mathrm{C}$. A constant voltage of $27 \mathrm{kV}$ was applied to the inlet of the capillary during analysis. Samples were injected by applying a pressure of 50 mbar for $4 \mathrm{~s}$. The capillary was rinsed with running buffer for $5 \mathrm{~min}$ between analyses. The on-line coupling of $\mathrm{CE}$ to the MS was achieved with a coaxial sheath liquid interface (Agilent Technologies), connected to an orthogonal electrospray ion source. A $5 \mathrm{mM}$ ammonium acetate solution in water/methanol $1 / 1$ was used as sheath liquid, delivered by a syringe pump at $4 \mu \mathrm{min}^{-1}$.

For direct mass spectra, solutions of the freeze dried samples of the enzyme assays in $0.01 \%$ trifluoroacetic acid in water were injected into the ESI source by a syringe pump at $6 \mu \mathrm{min}^{-1}$. Mass spectra were obtained using a Bruker ESQUIRE- 
LC ion-trap instrument (Bruker-Franzen $\mathrm{GmbH}$, Bremen, Germany). The MS detector was operated under the following conditions: nitrogen nebulizer gas, $10 \mathrm{psi}$; nitrogen dry gas, $101 \mathrm{~min}^{-1}$; dry temperature, $250^{\circ} \mathrm{C}$; capillary voltage, $4000 \mathrm{~V}$; end-plate $3500 \mathrm{~V}$; capillary exit, $65 \mathrm{~V}$; and skimmer $1,15 \mathrm{~V}$. The MS acquisitions were performed under ion charge control conditions $(10,000)$, and in the mass range from $m / z 50$ to 500 .

\section{Results}

Enzymatic consumption of $M M$ in cell-free extracts of strain MM 1

In enzyme assays, disappearance of the QAA MM was detected by ${ }^{1} \mathrm{H}$ NMR spectroscopy in the cellfree extract and in the PF of MM 1 cells grown with $\mathrm{MM}$ as sole source of carbon, energy and nitrogen. The course of the consumption of MM $(37 \mathrm{mM})$ in the PF $\left(0.4 \mathrm{mg} \mathrm{ml}^{-1}\right)$ is displayed in Figure 1.

No consumption of MM was found in enzyme assays performed with the soluble fraction and in control experiments with heat-inactivated extracts (cell-free extract, soluble fraction and PF). Thus, the observed disappearance of $\mathrm{MM}$ must be mediated by membrane-associated enzymes. Since the ${ }^{1} \mathrm{H}$ NMR spectra of reaction mixtures with the cell-free extract and the PF showed identical

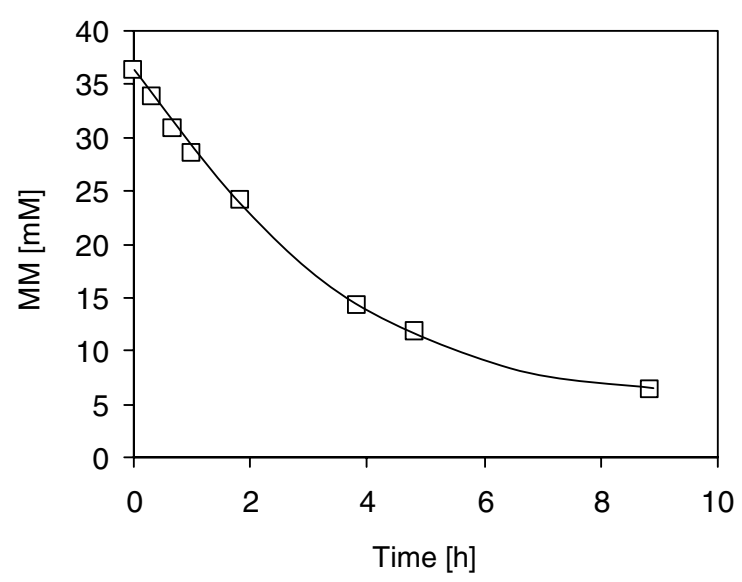

Figure 1. Consumption of $\mathrm{MM}$ in the $\mathrm{PF}$ of strain $\mathrm{MM} 1$ grown with $\mathrm{MM}$ (determined by ${ }^{1} \mathrm{H}$ NMR). An initial substrate concentration of $37 \mathrm{mM}$ and a protein concentration of $0.4 \mathrm{mg} \mathrm{ml}^{-1}$ was used in the assay. behavior (disappearance of substrate and formation of the same products), only the PF was used for further studies of the initial degradation step. Up to an initial MM concentration of $12 \mathrm{mM}$, the substrate was completely consumed and transformed into products within $2 \mathrm{~h}$ of incubation. Increasing the initial $\mathrm{MM}$ concentration to $37 \mathrm{mM}$ (Figure 1) and up to $90 \mathrm{mM}$, the amount of consumed MM decreased to 82 and $12 \%$, respectively.

Simple stirring of the reaction mixture in open vials was sufficient to maintain MM-consuming enzyme activity and no additional reaction partners were required. The addition of $\mathrm{NAD}^{+}$and $\mathrm{NADP}^{+}$to a final concentration of $2 \mathrm{mM}$ did not enhance this activity. However, under nitrogen atmosphere only a background activity for MM was detected (Figure 2, indicated by the initial slopes). This suggests an oxidative reaction to be responsible for the conversion of MM.

As alternatives to oxygen the electron acceptors PMS, NAD ${ }^{+}$and INT were tested under anoxic conditions. After incubation of enzyme assays for $3 \mathrm{~h}$ under nitrogen, the electron acceptors were added to the reaction mixture and the change in MM concentration was followed by ${ }^{1} \mathrm{H}$ NMR spectroscopy (Figure 2). PMS was the only reactant acting as alternative electron acceptor. This

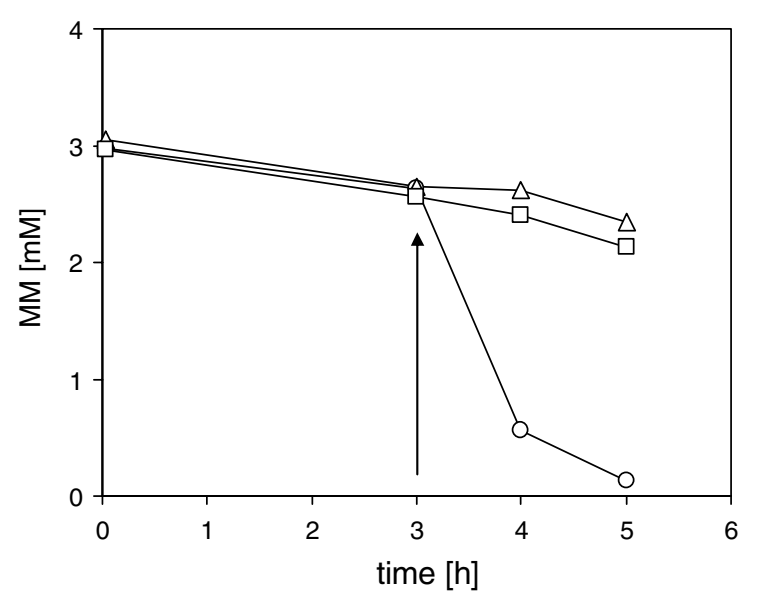

Figure 2. Consumption of $\mathrm{MM}(3 \mathrm{mM})$ in the particulate fraction of strain MM $1\left(0.43 \mathrm{mg} \mathrm{ml}^{-1}\right.$ of total protein) under anoxic conditions as determined by ${ }^{1} \mathrm{H}$ NMR spectroscopy. After $3 \mathrm{~h}$, the electron acceptors PMS $(\bigcirc, 4.5 \mathrm{mM}), \mathrm{NAD}^{+}(\triangle$, $3.2 \mathrm{mM}$ ), or INT $(\square, 0.5 \mathrm{ml}$ of a saturated stock solution in water to $4.5 \mathrm{ml}$ of the reaction mixture) were added to independent enzyme assays (arrow). Only PMS stimulated activity significantly. 
compound is known to act as a redox mediator for many redox enzymes for which the natural redoxmediating species are not known (Russell \& Scopes 1994).

Substrate preference and expression of enzymes in the PF of MM 1

The two structurally related substrates DM and choline were tested in the PF of MM 1 (cells grown with MM) under the same experimental conditions as those used for MM. The chemical structure of the substrates is shown in Figure 3. As for MM,<smiles>C[N+](C)(C)CC(=O)O</smiles>

(b)<smiles>[2H][N+]1([13CH3])[13CH2]O[13C@H](O)[13CH2]O1</smiles>
DM Oxidation product of DM

(c)<smiles></smiles><smiles>[R]C[N+]1(C)[C@@H]2CO[C@H](O)[C@H]1C2</smiles>
trans

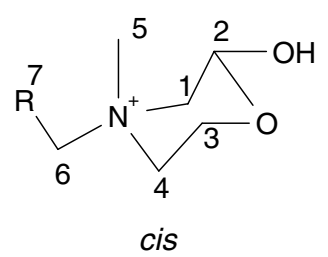

trans/cis-1: $\quad \mathrm{R}=\mathrm{CH}_{2} \mathrm{OH}$ trans/cis-2: $\mathrm{R}=\mathrm{CH}(\mathrm{OH})_{2}$ trans/cis-3: $\mathrm{R}=\mathrm{COOH}$

(d)<smiles>[Mg][Mg]</smiles><smiles>C[N+](C)(C)CC(O)CO</smiles>

Figure 3. Chemical structures of the substrates and their corresponding oxidation products (a) choline, (b) DM, (c) MM, (d) TM. Numbers indicate the position of carbon atoms used for NMR assignments. the enzyme activities with DM and choline were $\mathrm{O}_{2}$-dependent showing only a slight residual activity under nitrogen atmosphere, and again PMS was shown to act as electron acceptor under these conditions. In contrast, TM (Figure 3), another frequently applied head group QAA, was not converted at all.

The expression of the enzymes responsible for the oxidation of MM, DM or choline was studied with the PF of MM 1 cells, which were grown with substrates different from MM, namely with choline or acetate. Acetate was chosen as a growth substrate since it does not contain nitrogen and is normally catabolized via a different metabolic pathway compared to that known for choline.

The enzyme assays were performed with $0.5 \mathrm{mg} \mathrm{ml}^{-1}$ protein of the PF and $\sim 12 \mathrm{mM}$ of the carbon substrate. In all assays using the PF of choline or acetate grown MM 1 cells, transformation of MM, DM and choline to the corresponding products was observed as described above.

It should be pointed out that although strain MM 1 was unable to grow with DM, this QAA was transformed in the PF of MM-growing cells.

\section{Products from choline}

Two new signals from methyl groups of products were observed at 3.23 and 3.28 ppm in the ${ }^{1} \mathrm{H}$ NMR spectra of assays using the PF of strain MM 1 and choline additionally to the resonance line of the substrate. These products were identified as the primary and secondary oxidation products betainealdehyde (hydrated form, see Figure 3a) and betaine, respectively. The assignment of the NMR signals to the structures postulated was performed based on the ${ }^{1} \mathrm{H},{ }^{13} \mathrm{C}$ HSQC and HMBC spectra and/or addition of the pure compounds to the NMR solutions (for chemical shifts see Table 2). For betainealdeyde and betaine $\delta\left({ }^{14} \mathrm{~N}\right)$ values of -335.2 and $-334.9 \mathrm{ppm}$ were determined (line widths of 4.0 and $4.3 \mathrm{~Hz}$ ). The mass spectrum showed three signals at $m / z 104.2\left(\mathrm{M}^{+}\right.$, choline), $118.1\left(\mathrm{M}^{+}\right.$, betaine $)$and $120.1\left(\mathrm{M}^{+}\right.$, betainealdehyde-hydrate) and was identical to the mass spectrum of a mixture of the three pure compounds.

\section{Products from DM}

The consumption of DM in the PF enzyme assays was monitored by ${ }^{1} \mathrm{H}$ NMR. In the spectral region 
Table 2. ${ }^{1} \mathrm{H}$ and ${ }^{13} \mathrm{C}$ chemical shifts $[\mathrm{ppm}]$ of the products obtained from the degradation of choline and DM in the PF of strain MM 1

\begin{tabular}{|c|c|c|c|c|c|c|c|c|c|}
\hline \multirow[t]{2}{*}{ Position } & \multicolumn{3}{|c|}{ Betainealdehyde } & \multicolumn{3}{|l|}{ Betaine } & \multicolumn{3}{|c|}{ Oxidation product of DM } \\
\hline & No. of $\mathrm{H}$ & $\delta\left({ }^{1} \mathrm{H}\right)$ & $\delta\left({ }^{13} \mathrm{C}\right)$ & No. of $\mathrm{H}$ & $\delta\left({ }^{1} \mathrm{H}\right)$ & $\delta\left({ }^{13} \mathrm{C}\right)$ & No. of $\mathrm{H}$ & $\delta\left({ }^{1} \mathrm{H}\right)$ & $\delta\left({ }^{13} \mathrm{C}\right)$ \\
\hline 1 & 9 & 3.23 & 58.9 & 9 & 3.28 & 58.1 & 2 & $3.31 / 3.56$ & 67.3 \\
\hline 2 & 2 & 3.43 & 73.1 & 2 & 4.02 & 69.9 & 1 & 5.40 & 92.4 \\
\hline 3 & 1 & 5.56 & 89.6 & & & 173.0 & 2 & $4.03 / 4.34$ & 60.6 \\
\hline 4 & & & & & & & 2 & 3.52 & 64.7 \\
\hline 5 & & & & & & & 3 & 3.35 & 58.7 \\
\hline 6 & & & & & & & 3 & 3.26 & 57.6 \\
\hline
\end{tabular}

The positions of the carbon atoms in the molecule are shown in Figure 3.

of the $N$-methyl resonances two signals of equal intensities at 3.26 and $3.35 \mathrm{ppm}$ were detected. All observed ${ }^{1} \mathrm{H},{ }^{13} \mathrm{C}$ correlation signals (HSQC and HMBC) confirmed the postulated structure of the hemiacetale (Figure 3b). The chemical shift assignments are given in Table 2 . The correlations $\mathrm{H}-(2) / \mathrm{C}-(3), \mathrm{H}-(5) / \mathrm{C}-(1,4,6)$ and $\mathrm{H}-(6) / \mathrm{C}-(1,4,5)$ observed in the HMBC spectrum demonstrated the connectivity over the heteroatoms $\mathrm{N}$ and $\mathrm{O}$. The neighborhood of the anomeric proton $\mathrm{H}-(2)$ with the methyl group $\mathrm{H}-(6)$ was confirmed by ${ }^{1} \mathrm{H},{ }^{1} \mathrm{H}$ NOESY. A $\delta\left({ }^{14} \mathrm{~N}\right)$ of $-334.3 \mathrm{ppm}$ was determined, corresponding to a deshielding of $6.2 \mathrm{ppm}$ compared to the substrate signal. The line width of the product resonance $(1.5 \mathrm{~Hz})$ was only slightly enhanced compared to the substrate signal $(0.5 \mathrm{~Hz})$, demonstrating the relatively high symmetric substitution at the nitrogen atom. In the mass spectrum only two signals were present at $m / z 132.1\left(\mathrm{M}^{+}\right.$, oxidation product $)$and 134.1 $\left(\mathrm{M}^{+}, \mathrm{DM}\right)$.

\section{Products from MM}

The degradation of MM in the PF enzyme assays provided at first an unidentifiable mixture of products. In the ${ }^{1} \mathrm{H}$ NMR spectrum, at least seven different resonances of nitrogen-bound methyl groups were found in addition to the signal of the substrate MM (Figure 4b). As the assay proceeded, the signal of the methyl group of MM $(3.26 \mathrm{ppm})$ disappeared and the methyl resonances of primary products at 3.32 and $3.42 \mathrm{ppm}$ increased (assigned as trans/cis-1 in Figure 4). The primary products each exist as racemic mixtures of (2R, 4R)- and (2S, 4S)-2-hydroxy-4-(2-hydroxyethyl)-4-methyl-morpholin-4-ium (denoted as trans-1) and (2R, 4S)- and (2S, 4R)-2-hydroxy-4(2-hydroxy-ethyl)-4-methyl-morpholin-4-ium (denoted as cis-1). During reaction progress, these signals declined while several secondary product peaks increased (Figure 4c). To simplify the analysis of the spectra, MM was oxidized chemically since an oxidation was expected from the results obtained for choline and DM. The relevant section of a ${ }^{1} \mathrm{H}$ NMR spectrum of the synthesized product is shown in Figure 4a. Two singlet resonances of equal intensities (at 3.32 and $3.42 \mathrm{ppm}$ ) are observable next to the substrate signal (methyl groups of $\mathrm{MM}$ ). They correspond to the first evolving signals from the enzyme assay (Figure $4 b$ ). Based on the ${ }^{1} \mathrm{H}$ NMR spectrum two primary oxidation products (trans- and cis-1) were postulated (Figure 3c). The stereochemical relations cis or trans are defined by the relative configuration of the substituted carbon C-(6) to the $\mathrm{OH}$ group at the anomeric carbon C-(2). As soon as one ethanol group of MM was oxidized an intramolecular reaction with a second ethanol group lead to the cyclic, 6-membered hemiacetal, similar to the cyclic structures found in sugars (for glucose more than $99 \%$ is usually present in the hemiacetal form (Koolman \& Röhm 1998).

In the ${ }^{13} \mathrm{C}$ NMR spectrum 14 additional signals to the substrate signals were detected. The ${ }^{1} \mathrm{H},{ }^{13} \mathrm{C}$ HSQC showed distinct cross signals for 11 of these signals. Due to extensive overlapping of the correlation signals around $4.1 \mathrm{ppm}\left({ }^{1} \mathrm{H}\right)$ and $59.8 \mathrm{ppm}\left({ }^{13} \mathrm{C}\right)$ with the strong correlation signals of the residual substrate, no unequivocal assignments were possible. Definite assignment of the ${ }^{1} \mathrm{H}$ and ${ }^{13} \mathrm{C}$ chemical shifts of trans-1 $(\mathrm{H}-(3,4,7)$, $\mathrm{C}-(3,7))$ and cis-1 (H-(3, 7), C-(7)) was achieved by performing a HSQC-TOCSY experiment. The 


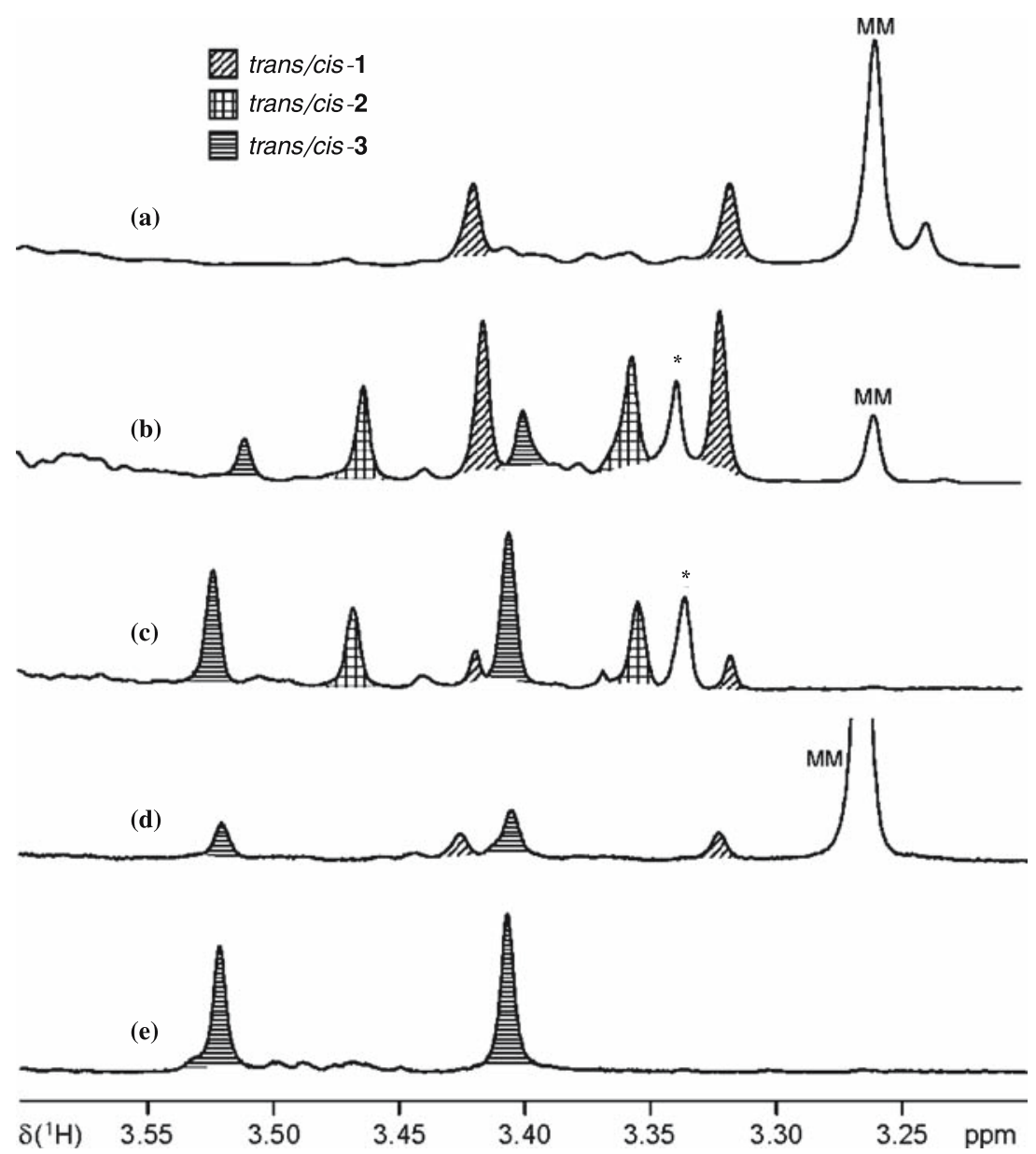

Figure 4. ${ }^{1} \mathrm{H}$ NMR spectral region of $N$-methyl groups with assignments of $\mathrm{MM}$ and its oxidation products (a) from chemical oxidation of MM, (b) from an enzyme assay using the PF of MM-grown cells of strain MM 1 with $37 \mathrm{mM}$ of $\mathrm{MM}, 0.5 \mathrm{mg} \mathrm{ml}^{-1}$ of protein, $12 \mathrm{~h}$ of incubation (* signal not assigned), (c) from a similar enzyme assay with $12 \mathrm{mM}$ of MM, $0.5 \mathrm{mg} \mathrm{ml}^{-1}$ of protein and $5 \mathrm{~h}$ of incubation, (d) from the culture liquid of strain MM 1 grown in batch culture with an initial concentration of $2 \mathrm{mM}$ of MM after $7 \mathrm{~h}$ of incubation (exponential phase) and, (e) from the same culture after $12 \mathrm{~h}$ (stationary phase) of incubation.

${ }^{1} \mathrm{H},{ }^{13} \mathrm{C}$ HMBC spectrum showed all crucial correlation signals across the heteroatoms $\mathrm{N}$ and $\mathrm{O}$, which were essential to confirm the product structures. Moreover, the correlation between the protons $\mathrm{H}-(2)$ and $\mathrm{H}-(5)$ (Figure 3c) found in the ${ }^{1} \mathrm{H},{ }^{1} \mathrm{H}$ NOESY spectrum confirmed the relative configuration of cis-1. The corresponding protons of trans 1 did not show any cross signal. The ${ }^{14} \mathrm{~N}$ NMR signals were assigned via ${ }^{1} \mathrm{H},{ }^{14} \mathrm{~N}$ HMQC correlation of the methyl protons at 3.32 and $3.42 \mathrm{ppm}$ with the ${ }^{14} \mathrm{~N}$ resonances of both diastereomers at $-329.0 \mathrm{ppm}$ (trans-1) and $-327.8 \mathrm{ppm}$ (cis-1) showing line widths $\Delta v_{1 / 2}$ of 2.5 and $2.3 \mathrm{~Hz}$. The average of chemical shift $\left(\delta\left({ }^{14} \mathrm{~N}\right)=-328.4 \mathrm{ppm}\right)$ showed a shielding of
$5.9 \mathrm{ppm}$ relative to the ${ }^{14} \mathrm{~N}$ signal of the substrate, comparable to the shielding of $6.2 \mathrm{ppm}$ found for DM and its oxidation product. All chemical shifts of trans- and cis-1 are shown in Table 3. The synthesized oxidation product trans/ cis-1 could be separated from MM by capillary electrophoresis using $10 \mathrm{mM}$ ammonium acetate in water $(\mathrm{pH}=6.8)$ as running buffer. MS detection at $m / z 164\left(\mathbf{M}^{+}\right.$, MM) showed a signal at $5.2 \mathrm{~min}$, while detection at $\mathrm{m} / \mathrm{z} 162$ indicated elution of trans/cis-1 at $5.1 \mathrm{~min}$.

In the ${ }^{1} \mathrm{H}$ NMR spectrum of an enzyme assay performed with MM at least five additional signals with significant intensities were observed (Figures $4 \mathrm{~b}$ and c), belonging to the $N$-methyl groups 
Table 3. ${ }^{1} \mathrm{H}$ and ${ }^{13} \mathrm{C}$ chemical shifts $[\mathrm{ppm}]$ of the products found by degradation of MM in the PF of strain MM 1

\begin{tabular}{|c|c|c|c|c|c|}
\hline \multicolumn{2}{|c|}{ Primary products } & \multicolumn{2}{|c|}{ trans $-\mathbf{1}$} & \multicolumn{2}{|c|}{ cis-1 } \\
\hline Position & Number of $\mathrm{H}$ & $\delta\left({ }^{1} \mathrm{H}\right)$ & $\delta\left({ }^{13} \mathrm{C}\right)$ & $\delta\left({ }^{1} \mathrm{H}\right)$ & $\delta\left({ }^{13} \mathrm{C}\right)$ \\
\hline 1 & 2 & $3.39 / 3.69$ & 66.6 & $3.39 / 3.61$ & 66.7 \\
\hline 2 & 1 & 5.44 & 92.4 & 5.41 & 92.3 \\
\hline 3 & 2 & $4.05 / 4.40$ & 60.0 & $4.09 / 4.31$ & 61.0 \\
\hline 4 & 2 & $3.57 / 3.69$ & 64.3 & $3.59 / 3.65$ & 64.2 \\
\hline 5 & 3 & 3.42 & 55.5 & 3.32 & 54.1 \\
\hline 6 & 2 & 3.65 & 71.2 & 3.78 & 72.1 \\
\hline 7 & 2 & 4.12 & 59.4 & 4.12 & 59.6 \\
\hline \multicolumn{2}{|c|}{ Second. products } & \multicolumn{2}{|c|}{ trans-2 } & \multicolumn{2}{|c|}{ cis-2 } \\
\hline Position & Number of $\mathrm{H}$ & $\delta\left({ }^{1} \mathrm{H}\right)$ & $\delta\left({ }^{13} \mathrm{C}\right)$ & $\delta\left({ }^{1} \mathrm{H}\right)$ & $\delta\left({ }^{13} \mathrm{C}\right)$ \\
\hline 1 & 2 & $*$ & * & * & $*$ \\
\hline 2 & 1 & * & * & 5.40 & $*$ \\
\hline 3 & 2 & $*$ & $*$ & $*$ & $*$ \\
\hline 4 & 2 & $3.58 / 3.74$ & 64.8 & $3.61 / 3.69$ & 64.7 \\
\hline 5 & 3 & 3.46 & 55.8 & 3.36 & 54.6 \\
\hline 6 & 2 & $*$ & $*$ & $*$ & $*$ \\
\hline 7 & 1 & 5.64 & 89.1 & 5.66 & 89.3 \\
\hline \multicolumn{2}{|c|}{ Tert. products } & \multicolumn{2}{|c|}{ trans $-\mathbf{3}$} & \multicolumn{2}{|c|}{ cis-3 } \\
\hline Position & Number of $\mathrm{H}$ & $\delta\left({ }^{1} \mathrm{H}\right)$ & $\delta\left({ }^{13} \mathrm{C}\right)$ & $\delta\left({ }^{1} \mathrm{H}\right)$ & $\delta\left({ }^{13} \mathrm{C}\right)$ \\
\hline 1 & 2 & $3.50 / 3.85$ & 66.0 & 3.66 & 65.8 \\
\hline 2 & 1 & 5.42 & 92.5 & 5.40 & 92.5 \\
\hline 3 & 2 & $4.03 / 4.40$ & 60.1 & $4.09 / 4.32$ & 60.8 \\
\hline 4 & 2 & $3.61 / 3.87$ & 63.7 & $3.66 / 3.76$ & 63.9 \\
\hline 5 & 3 & 3.52 & 55.5 & 3.41 & 54.6 \\
\hline 6 & 2 & 4.02 & 69.7 & $4.09 / 4.24$ & 70.0 \\
\hline 7 & & & 172.9 & & 173.4 \\
\hline
\end{tabular}

The positions of the carbon atoms in the molecules are shown in Figure 3c.

$*$ Not assigned.

of further products. In the ${ }^{1} \mathrm{H},{ }^{13} \mathrm{C}$-HMBC spectrum (correlation of the chemical shifts over 2-3 atom bonds) explicit cross signals of protons in the region of 4.0-4.2 ppm with carbon atoms at 172.9 and $173.4 \mathrm{ppm}$ were detected. Each of these proton signals correlated with three further carbon atoms providing very similar chemical shifts as found for the products trans- and cis-1. Based on these findings, the two tertiary oxidation products assigned as trans- and cis-3 (Figure 3c) were postulated with the ${ }^{1} \mathrm{H}$ resonances of the methyl groups at 3.41 and $3.52 \mathrm{ppm}$. The two compounds are cyclic hemiacetals as described for the primary products with the third ethanol group oxidized to the corresponding carboxylic acid. The chemical shifts $\delta\left({ }^{1} \mathrm{H}\right)$ and $\delta\left({ }^{13} \mathrm{C}\right)$ of trans- and cis-3 are given in Table 3. Again, both products were found in equimolar amounts as racemic mixtures of $(2 R$, $4 \mathrm{~S})$ - and (2S, 4R)-4-carboxymethyl-2-hydroxy-4methyl-morpholin-4-ium (denoted as trans-3) and (2R, 4R)- and (2S, 4S)-4-carboxymethyl-2-hydroxy-4-methyl-morpholin-4-ium (denoted as cis3).

The ${ }^{1} \mathrm{H},{ }^{13} \mathrm{C}$ HMBC correlation of the methyl protons in position 5 with the carbon atoms 1,4 and 6 (Figure 3c) as well as the correlations found with the ${ }^{1} \mathrm{H},{ }^{13} \mathrm{C}$ HSQC spectrum confirmed the structural elements linked to the nitrogen atoms. The ${ }^{1} \mathrm{H},{ }^{13} \mathrm{C}$ HSQC-TOCSY experiment provided the assignment of the ${ }^{1} \mathrm{H}$ and ${ }^{13} \mathrm{C}$ chemical shifts at positions 2 and 3 (Table 3). The ${ }^{1} \mathrm{H},{ }^{1} \mathrm{H}$ NOESY spectrum showed unequivocally that the signal of the methyl group at $3.41 \mathrm{ppm}$ correlated with $\mathrm{H}-(2)$, therefore confirming the relative configuration of the structure cis-3. The stereochemistry of trans-3 was confirmed via the correlation between the protons $\mathrm{H}-(6)$ and $\mathrm{H}-(2)$. In the $1 \mathrm{D}{ }^{14} \mathrm{~N}$ NMR spectra the signals of the different products were not resolved clearly due to signal overlapping, and in samples with low product concentrations these signals were hardly detectable. Therefore, the assignment of the signals to the structures trans- and cis-3 was performed via the ${ }^{1} \mathrm{H},{ }^{14} \mathrm{~N}$ HMQC correlation $\left(\delta\left({ }^{14} \mathrm{~N}\right)\right.$ : trans-3: -330.5 ppm; cis-3: -329.9 ppm; Figure 5). The CE-MS spectra of this assay using a running buffer of $10 \mathrm{mM}$ ammonium acetate in water $(\mathrm{pH}=6.8)$ showed three signals for the masses $m / z 164\left(\mathrm{M}^{+}\right.$, $\mathrm{MM})$ at $5.0 \mathrm{~min}, 162\left(\mathrm{M}^{+}\right.$, trans $/$cis-1) at $4.9 \mathrm{~min}$ and $176\left(\mathrm{M}^{+}\right.$, trans $/$cis-3) at $7.1 \mathrm{~min}$. The retention times for $\mathrm{MM}$ and trans/cis-1 are in accordance to chemically oxidized MM. Because it is a dipolar ion, the retention time of trans/cis-3 is much longer compared to MM.

Additionally to the previously assigned ${ }^{1} \mathrm{H}$ NMR signals, two further methyl singlet resonances were detected at 3.36 and $3.46 \mathrm{ppm}$ (Figures $4 \mathrm{~b}$ and $\mathrm{c}$ ), which were supposed to belong to the intermediate cyclic products trans- and cis-2 (hydrated form of the aldehyde). The systematic names of the racemic mixture of these acetals are (2R, 4R)- and (2S, 4S)-4-(2,2-dihydroxy-ethyl)-2hydroxy-4-methyl-morpholin-4-ium (trans-2) and 


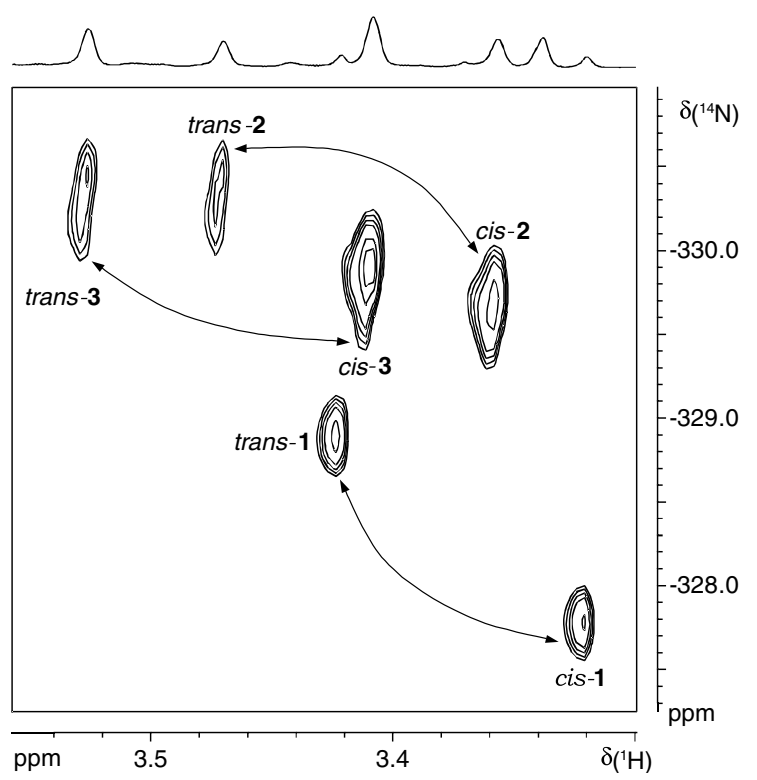

Figure 5. ${ }^{1} \mathrm{H},{ }^{14} \mathrm{~N}$ HMQC spectrum with assignment of signals to the oxidation products trans/cis-1, 2 and $\mathbf{3}$ (experimental setup as in Figure 4c). MM was completely converted to products under these conditions.

(2R, 4S)- and (2S, 4R)-4-(2,2-dihydroxy-ethyl)-2hydroxy-4-methyl-morpholin-4-ium (cis-2).

Since most resonances of the ${ }^{1} \mathrm{H}$ and ${ }^{13} \mathrm{C}$ signals probably lay beyond the signals of trans/cis-1, trans/cis-3 and MM, no final prove of cis- and trans-2 was possible by NMR spectroscopy. However, several indications were found for their existence and the chemical shifts $\delta\left({ }^{1} \mathrm{H}\right)$ and $\delta\left({ }^{13} \mathrm{C}\right)$ giving evidence to trans/cis-2 structures are listed in Table 3. The ${ }^{1} \mathrm{H},{ }^{13} \mathrm{C}$ HMBC correlations of the methyl protons H-(5) (Figure 3c) showed correlation signals to the carbon atoms at 64.7 and $64.8 \mathrm{ppm}$ (probably C-(4)). Unfortunately the correlation signals to $\mathrm{C}$-(1) and $\mathrm{C}$-(6) were not detectable. Additional hints for the expected structures were observed in the ${ }^{1} \mathrm{H},{ }^{1} \mathrm{H}$ NOESY spectrum: trans-2 showed a correlation signal of $\mathrm{H}-(5)$ with $\mathrm{H}-(7)$, whereas for cis-2 a correlation of $\mathrm{H}-(5)$ with $\mathrm{H}-(7)$ as well as with $\mathrm{H}-(2)$ was detected. Based on this steric interaction the relative configuration of cis-2 at the nitrogen atom was deduced. ${ }^{14} \mathrm{~N}$ chemical shifts of $-330.3 \mathrm{ppm}$ (trans-2) and -329.7 ppm (cis-2) were observed (Figure 5).

The existence of the intermediate products trans/cis-2 was confirmed by CE-MS experiments that showed masses at $m / z 164\left(\mathbf{M}^{+}, \mathrm{MM}\right), 178$ $\left(\mathrm{M}^{+}\right.$, trans/cis-2) and 160 . The mass $m / z 160$ was assigned to a bicyclic acetal 2a (Figure 6). Unfortunately the three masses co-eluted at $4.9 \mathrm{~min}$ if $10 \mathrm{mM}$ ammonium acetate in water $(\mathrm{pH}=6.8)$ was used as running buffer. When the buffer was changed to $5 \mathrm{mM}$ ammonium acetate in water/ methanol 1:1, the signal for $m / z 164\left(\mathrm{M}^{+}, \mathrm{MM}\right)$ appeared after $12.3 \mathrm{~min}$, while a new signal at $\mathrm{m} / \mathrm{z}$ 192 was detected. This signal appeared after 12.6 min together with the now much weaker signals at $m / z 178$ and 160 (Figure 6). Obviously trans/cis-2 and 2a were mostly converted to the methanol hemiacetal $\mathbf{2 b}$ in the methanolic buffer. Because of this observation we also assume that acetal 2a is in a dynamic equilibrium with cis-2 in aqueous solution.

All pairs of diastereomers showed a stronger shielding of the nitrogen nucleus in the cis-configuration compared to the trans isomers. We could not identify the structure of the product with its methyl singlet at $3.34 \mathrm{ppm}$ indicated with * in Figures $4 \mathrm{~b}$ and $\mathrm{c}$, possibly it originates from a structure different to a $N$-methyl group, since no ${ }^{1} \mathrm{H}-{ }^{14} \mathrm{~N}$ correlation signal was observable.

During batch growth of strain MM 1 the substrate MM continuously decreased in the exponential phase until it had completely disappeared when reaching the stationary phase after about $11 \mathrm{~h}$ (Kaech 2002). However, at the end of such batch cultures, high residual concentrations of carbon and organic nitrogen were left in the culture broth. Therefore, supernatants of batch cultures in the exponential and stationary phase were investigated by ${ }^{1} \mathrm{H}$ NMR spectroscopy with respect to the presence of excreted metabolites. The primary and tertiary oxidation products trans/cis-1 and 3 (Figure 4d) were identified in the culture liquid as major excreted metabolites in the supernatants of batch cultures in the exponential phase. In the stationary phase exclusively trans/cis-3 (Figure 4e) was detected. Based on the measured residual carbon and organic nitrogen concentrations (Kaech 2002) these products accumulated during the exponential growth phase to a maximum final concentration of $30 \mathrm{~mol} \%$ of the initially provided MM.

\section{Discussion}

All detected enzyme activities were associated with the (cytoplasmic) membrane of strain MM 1 

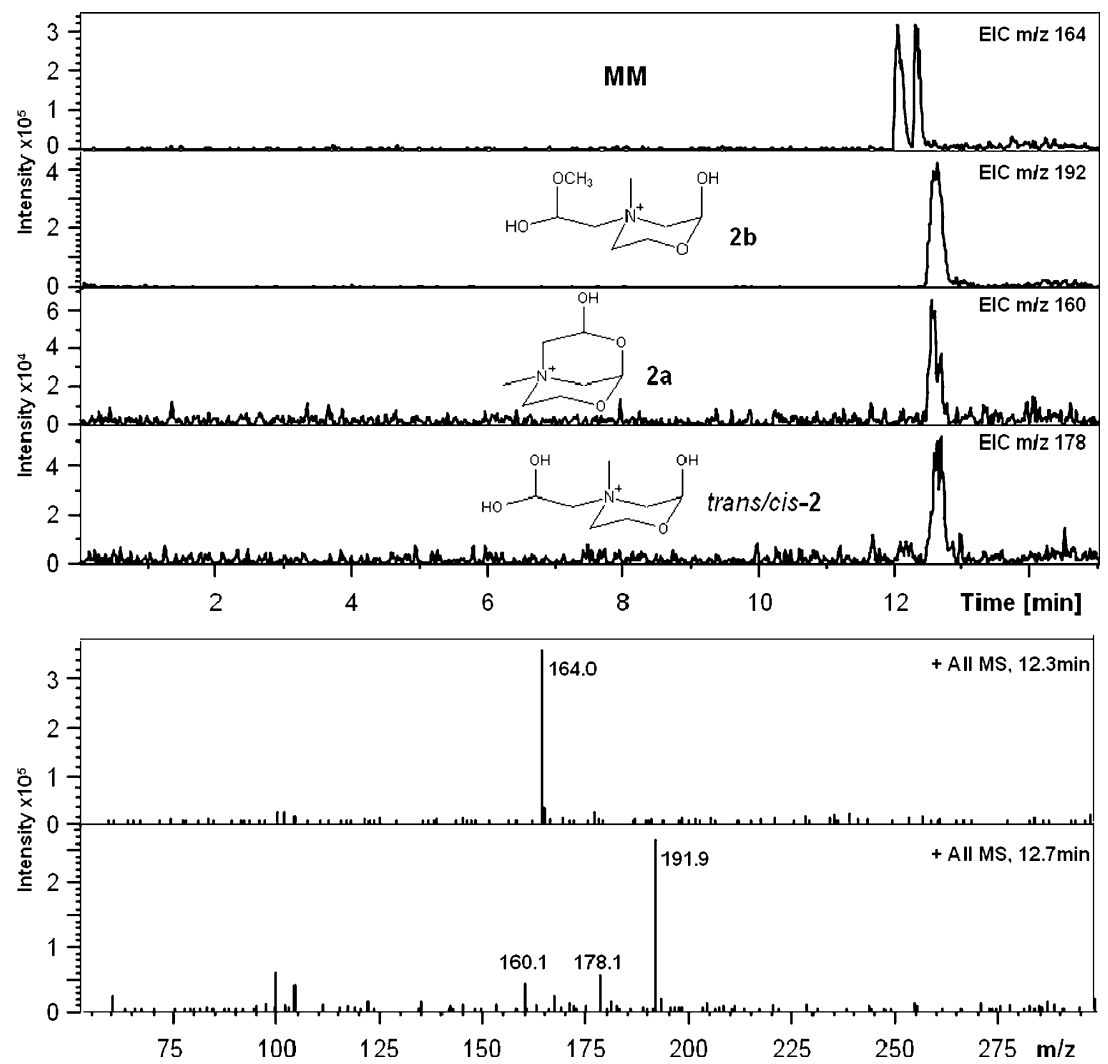

Figure 6. CE-MS experiments: Extracted ion chromatograms for $m / z 164$ (MM), 192 (2b), 160 (2a), and 178 (trans/cis-2) are shown. The mass spectrum at $12.3 \mathrm{~min}$ shows only MM, while in the mass spectrum at $12.7 \mathrm{~min} 2 \mathbf{b}$ predominates.

making purification of the enzymes a challenge. Nevertheless, the initial steps of the catabolic pathway could be investigated with enzyme assays using the PF of strain MM 1. From these assays a cascade of three pairs of increasingly oxidized cyclic products (trans/cis-1, $\mathbf{2}$ and $\mathbf{3}$ ) of MM were identified, each of them existing as a 1:1 mixture of two diastereomers. This observation may be interpreted in two ways: Either the oxidation to the cyclic hemiacetals was not diastereoselective and/or they underwent subsequently intramolecular rearrangements with the remaining ethanol group in aqueous solution. Conversion of MM was detected only in presence of oxygen. If anaerobic conditions were employed, no metabolites of MM were observed. The addition of the electron accepting reagent PMS to enzyme assays under nitrogen atmosphere induced resumption of the process. The carboxylic acid metabolites trans/ cis-3 are most likely dead-end metabolites, because considerable amounts of these compounds were released into the culture broth and remained un- touched in batch cultures of strain MM 1. Consequently, one has to take into account that these metabolites may accumulate in the environment. To investigate the possible presence of these compounds, detailed studies of complex environmental systems, i.e. river water or sewage treatment sludge should be performed and the evidence of such metabolites would greatly influence the design of new head groups used in esterquat surfactants.

The two ammonium alcohols DM and choline, both closely related to the chemical structure of MM, were metabolized by the PF of strain MM 1 under the same experimental conditions as used for MM (aerobic or anaerobic with PMS). Whereas for choline the well-known oxidation products betainealdehyde and betaine were found, the structure of a cyclic hemiacetal has been identified for DM as single metabolite. For TM, a substrate structurally related to choline, no catabolic activity was observed with strain MM 1 . Based on these findings, the following conclusions 
can be drawn with respect to the described enzymatic activity. Free ethanol groups, as present in MM, DM and choline, are essential to undergo oxidation in the active enzyme and/or the 2,3-dihydroxy-propyl part of TM prevented the molecule to fit into the active site. Obviously, the presence of quaternary nitrogen atoms was not sufficient to allow enzymatic oxidation of the hydroxyl groups.

The cultivation of strain MM 1 was also successfully performed when choline or acetate (together with ammonium chloride as nitrogen source) served as growth substrates, whereas for DM no growth has been observed. For the substrates MM, DM and choline the same metabolites as for MM-grown bacteria have been identified from enzyme assays using the PFs of MM 1 cultivated in choline or acetate media.

The enzyme responsible for the initial degradation of MM probably belongs to the group of membrane-associated oxidoreductases. Since both oxidation steps of choline and DM proceeded under the same conditions as found for MM and the formation of identical metabolites occurred as well with the PF of acetate and choline grown cells, both oxidation steps are probably mediated by one and the same enzyme. Obviously, the continuing degradation of the ring structure is not mediated by this "MM-oxidoreductase" since the cyclic hemiacetals were not further oxidized or metabolized. Owing to the ability of strain MM 1 to grow with choline and the fact that oxidation of choline is widespread amongst microorganisms (Kortstee 1970), the enzyme described may be a choline oxidoreductase with a broad substrate tolerance. Membrane-associated oxidoreductases consuming choline with similar properties as described here were also detected in Pseudomonas aeruginosa and Escherichia coli (Bater \& Venables 1977; Lamark et al. 1991; Nagasawa et al. 1976; Russell \& Scopes 1994). However, these oxidoreductases (choline dehydrogenases) specifically oxidized choline to betainealdehyde only, without further oxidation to betaine. Enzymes mediating additionally the oxidation step to the carboxylic acid were characterized by Ohta-Fukuyama et al. (1980) and Ikuta et al. (1977) from Alcaligenes sp. and Arthrobacter globiformis, respectively, although these enzymes were not membrane associated.

The presented study suggests that the oxidation of MM might be linked to the oxidation of cho- line. This raises the question, whether the degradation of QAAs generally is related to the choline degradation pathway or whether different strategies are responsible for the catabolism of variable QAAs.

\section{Acknowledgments}

The authors are indebted to Steve Hales for initiating this work and to Naheed Rehman, SEAC- Applied Science \& Technology, Unilever Colworth, UK for support and fruitful discussions. We also thank Werner Angst and Alexander J. B. Zehnder for valuable discussions, suggestions and support throughout this work. This study was financed by SEAC - Applied Science \& Technology, Unilever Colworth, UK.

\section{References}

Bater AJ \& Venables WA (1977) The characterization of inducible dehydrogenases specific for the oxidation of D-alanine, allohydroxy-D-proline, choline and sarcosine as peripheral membrane proteins in Pseudomonas aeruginosa. Biochim. Biophys. Acta 468: 209-226

Bax A (1985) A spatially selective composite 90 degrees radiofrequency pulse. J. Magn. Reson. 65: 142-145

Bax A, Griffey RH \& Hawkins BL (1983) Correlation of proton and N-15 chemical-shifts by multiple quantum NMR. J. Magn. Reson. 55: 301-315

Davis AL, Keeler J, Laue ED \& Moskau D (1992) Experiments for recording pure-absorption heteronuclear correlation spectra using pulsed field gradients. J. Magn. Reson. 98: 207-216

Dess DB \& Martin JC (1983) Readily accessible 12-I-5 oxidant for the conversion of primary and secondary alcohols to aldehydes and ketones. J. Org. Chem. 48: 4155-4156

Hellberg PE, Bergstroem K \& Holmberg K (2000) Cleavable surfactants. J. Surf. Det. 3: 81-91

Ikuta S, Matuura K, Imamura S, Misaki H \& Horiuti Y (1977) Oxidative pathway of choline to betaine in the soluble fraction prepared from Arthrobacter globiformis. J. Biochem. (Tokyo) 82: 157-163

Jeener J, Meier BH, Bachman P \& Ernst RR (1979) Investigation of exchange processes by two-dimensional NMR spectroscopy. J. Chem. Phys. 71: 4546-4553

Kaech (2002) Microbial degradation of quaternary ammonium alcohols - hydrolysis products of esterquat surfactants used as fabric softeners. Diss. ETH Nr. 14757. Swiss Federal Institute of Technology, Zurich

Koolman J \& Röhm KH (1998) Taschenatlas der Biochemie. Georg Thieme Verlag, Stuttgart, New York

Kortstee GJJ (1970) The aerobic decomposition of choline by microorganisms. Arch. Microbiol. 71: 235-244 
Krueger G, Boltersdorf D \& Overkempe K (1998) Esterquats. In: Holmberg K (Ed) Novel Surfactants (pp 116-139). Marcel Dekker, New York

Lamark D, Kaasen I, Eshoo MW, Falkenberg P, McDougall J \& Strom AR (1991) DNA sequence and analysis of the bet genes encoding the osmoregulatory choline-glycine betaine pathway of Escherichia coli. Mol. Microbiol. 5: 1049-1064

Nagasawa T, Mori N, Tani Y \& Ogata K (1976) Characerization of choline dehydrogenase from Pseudomonas aeruginosa A-16. Agric. Biol. Chem. 40: 2077-2084

Ogawa A \& Curran DP (1997) Benzotrifluorid: A useful alternative solvent for organic reactions currently conducted in dichloromethane and related solvents. J. Org. Chem. 62: $450-451$

Ohta-Fukuyama M, Miyake Y, Emi S \& Yamano T (1980) Identification and properties of the prosthetic group of choline oxidase from Alcaligenes sp. J. Biochem. (Tokyo) 88: 197-203

Palmer AG, Cavanagh J, Wright PE \& Rance M (1991) Sensitivity improvement in proton-detected 2-dimensional heteronuclear correlation NMR-spectroscopy. J. Magn. Reson. 93: 515-170

Pfennig N, Widdel F \& Trueper HG (1981) The dissimilatory sulfate-reducing bacteria. In: Starr MP, Stolp H, Trueper HG, Balows A \& Schlegel HG (Eds) The Prokaryotes, Vol. I (p 931). Springer Verlag, Berlin
Puchta R, Krings P \& Sandkühler P (1993) A new generation of softeners. Tenside Surfact Det. 30: 186-191

Russell R \& Scopes RK (1994) Use of hydrophobic chromatography for purification of the membrane-located choline dehydrogenase from a Pseudomonas strain. Bioseparation 4: 279-284

Shaka AJ, Barker PB \& Freeman R (1985) Computeroptimized decoupling scheme for wideband applications and low-level operation. J. Magn. Reson. 64: 547-552

Shaka AJ, Keeler J, Frenkiel T \& Freeman R (1983) An improved sequence for broadband decoupling: WALTZ-16. J. Magn. Reson. 52: 335-338

Simms JR, Woods DA, Walley DR, Keough T, Schwab BS \& Larson RJ (1992) Integrated approach to surfactant environmental safety assessment: fast atom bombardment mass spectrometry and liquid scintillation counting to determine the mechanism and kinetics of surfactant biodegradation. Anal. Chem. 64: 2951-2957

Waters J, Lee KS, Perchard V, Flanagan M \& Clarke P (2000) Monitoring of diester cationic surfactant residues in UK and Dutch sewage treatment effluents. Tenside Surf. Det. 37: 161171

Wilker W, Leibfritz D, Kerssebaum R \& Bermel W (1993) Gradient selection in inverse heteronuclear correlation spectroscopy. J. Magn. Reson. 78: 287-292 